\title{
Banking Ecosystem: What Do Retail Clients Expect from the Modern Financial Services Industry?
}

\author{
Cam-Duc Au ${ }^{1,2, *}$, Philippe Krahnhof ${ }^{1,2}$, Lars Klingenberger ${ }^{1,2}$ \\ ${ }^{1}$ Department of Finance, Faculty of Economics and Administration, Masaryk University, Czech Republic \\ ${ }^{2}$ FOM University of Applied Sciences for Economics and Management, Germany
}

Received November 29, 2021; Revised January 13, 2022; Accepted February 8, 2022

\section{Cite This Paper in the following Citation Styles}

(a): [1] Cam-Duc Au, Philippe Krahnhof, Lars Klingenberger, "Banking Ecosystem: What Do Retail Clients Expect from the Modern Financial Services Industry?," Universal Journal of Accounting and Finance, Vol. 10, No. 2, pp. 498 508, 2022. DOI: 10.13189/ujaf.2022.100214.

(b): Cam-Duc Au, Philippe Krahnhof, Lars Klingenberger (2022). Banking Ecosystem: What Do Retail Clients Expect from the Modern Financial Services Industry?. Universal Journal of Accounting and Finance, 10(2), 498 - 508. DOI: 10.13189/ujaf.2022.100214.

Copyright $\mathrm{C} 2022$ by authors, all rights reserved. Authors agree that this article remains permanently open access under the terms of the Creative Commons Attribution License 4.0 International License

\begin{abstract}
German banks are experiencing harsh times due to rising costs and declining profits. On the one hand, acquisition costs for new customers are increasing because of the rise of innovative FinTechs, which entered the market with one specific goal: disrupting the whole financial services industry by occupying parts of the value-chain. On the other hand, the Covid-19 pandemic as well as an overall low level of interest rates cause the traditional source of bank income to still drain. Consequently, traditional banks must rethink their strategies or their identity, so to speak, because they go beyond their traditional offering of products and services. Having said that, banks may create new sources of income to stabilize their economic situation and replenish profits. The given paper aims to research the opportunities of establishing an ecosystem model. In doing so, the paper contributes to the current literature debate and provides reference points for traditional banks to start. Firstly, a systematic literature-review introduces a selection of research works the author regards as significant. In the following step, quantitative data from an online survey with bank clients is analysed by means of descriptive statistics to show the perspective of Germans with regards to an ecosystem offering. The final research findings indicate that the surveyed retail banking clients express interest in the new offer, whereas non-financial products and services are of lower interest than their financial pendants.
\end{abstract}

Keywords Banking, Ecosystem, Disruptive
Innovation, Digital Offering, Open-Banking-Strategy, Financial Services Industry

\section{Introduction}

Traditional bank institutions are used to be dominant market incumbents when it comes to the financial services industry. However, due to the Financial Crisis in 2007 and the corresponding lack of trust in advisory services, banks lost significant trust. Not only bank customers but also financial regulators are still doubting the business operations as well as practices, thereby leading to harsher regulatory requirements. This entails higher expenses to move and operate within the regulatory framework, which is aiming for vital parts in the banking operations. Therefore, banks are facing higher costs or expensive for running their businesses. Moreover, the loss of customer trust appears in declining sales figures because due to negative experiences in fields such as mortgage or investment advice. Customers hence are looking for alternative market players to deal with their financial matters. As a matter of fact, young and innovative StartUps or FinTechs are experiencing high attention by bank customers. Balyuk et al. examined the example of the platform lending market, which is currently entered by innovative FinTechs. The authors concluded that FinTechs are aware of how to purposefully use customer data to gain a better market position and outperform traditional banks 
with their traditional methods [1]. In general, new market players often aim to provide better products and services than their traditional counterparts. They purposefully disrupt parts of the value chain and offer specialized offerings to convince customers. Consequentially, traditional banks are currently losing market shares to the young market players, thereby leading to declining earnings. Gianiodis et al. emphasize that the power of innovation is continuing to foster economic growth. The result is based on a comparison case study of two major and well-established banks. The authors stress that banks are well advised to focus on the innovation process within the organization to keep pace with the current innovative developments. [5]. Ryan et al. state in their research that FinTechs, in this case a P2P-lender, are already successfully using new technology or artificial intelligence in the form of machine learning. The finding stresses that banks may observe and learn from innovative competitors to strengthen their own business methods or practices [11]. In addition, the Covid-19 pandemic troubles the profit situation of banks due to depreciations of big engagements in loan businesses. The pandemic shows the vulnerability of the already troubled situation of traditional banks. Therefore, many banks started to seek new profitable markets for establishing new sources of income.

In the debate of new revenue streams, the term of "beyond banking", "banking ecosystem" and "open banking" is mainly used to illustrate a new way of thinking. The term of "beyond banking" stands for an approach in which a traditional bank is seeking for new revenues beyond the classic financial products and services. Figure 1 presents the RoE from selected banks in the timeline starting from 2008 until 2018. It becomes clear, that German banks show a RoE of roughly $1 \%$, thereby being far behind American competitors as well as behind other
European and Asian banks. The illustrated facts underline the necessity of German banks to work on their economic situation by introducing new sources of income and regaining international competitiveness.

Kader sees a customer-centric approach as key to understanding changing customer needs better and providing the right products as well as services. BigTechs like Google, Amazon or Apple are exemplary experts in understanding customers and banks can learn from that [7]. Products such as loans, deposits and accounts rank among the traditional banking offerings. Going beyond this offering implies for instance tax services, personal finance management tools or non-financial products and services such as vouchers, digital safe or digital identity manager. According to Brackert et al., it is important for banks to introduce modern solutions to attract new and especially young customers. The authors emphasize the importance of younger customer generations because they are the foundation for future profits. Losing them to FinTechs may be a significant competitive disadvantage [3]. Banks often refer to successful best practice examples from American companies such as Uber or Airbnb. Both mentioned examples went beyond the traditional offering and established a platform in which demand and supply are brought together, thereby receiving a commission payment for the successful transaction. Airbnb became successful without possessing any real estate at all, which demonstrates the change in the way of thinking about business and going beyond. Uber did the same without possessing any cars at all and by providing an app to match taxi driver and customer. The conclusion banks are currently drawing from these examples is to think beyond business boarders and try to achieve a new way of banking business.

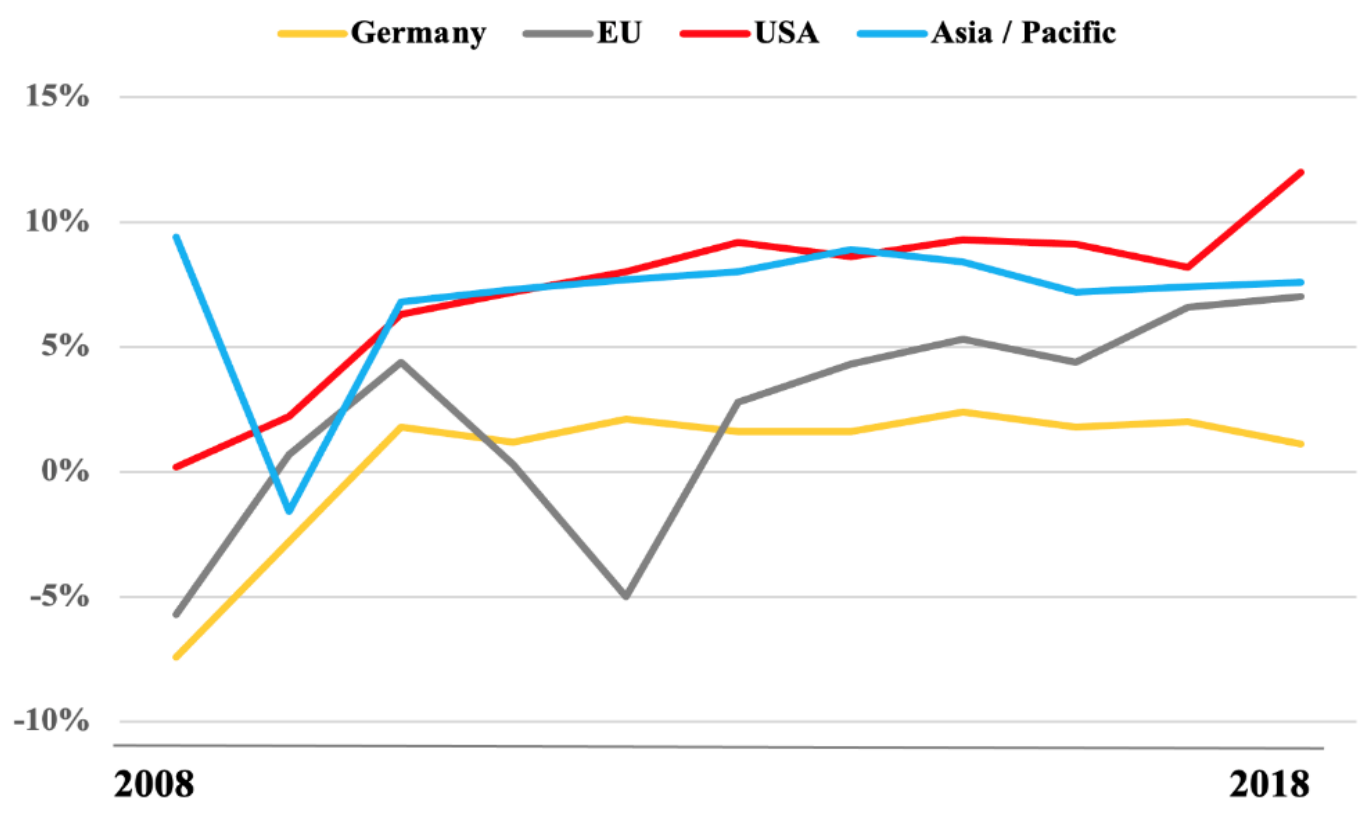

Source. Own research and illustration according to Bloomberg data

Figure 1. Return on Equity (RoE) from selected banks 
The term of "banking ecosystem" is connected to the concept of going beyond the traditional offering. An ecosystem in the banking context implies the integration of products and services from third-party-providers. A bank, which lacks a certain product or service (e.g., P2P-Lending, crowdfunding), may find a strategic partner to offer the product to the own customers. Integrating a variety of third-party-providers will lead to an ecosystem around the own bank, which is accessible for customers. In doing so, it is likely to keep the customers satisfied and to reduce the risk of customer churn because requested products and services from third-party-providers are available at the house bank. Standaert et al. show in their development of a framework that banks with dominant positions are doing well when opening for innovation and a new way of product and service offering [12]. One exemplary offer is the product of $\mathrm{P} 2 \mathrm{P}$-lendings, which implies two private persons in a loan agreement. Jun and Yeo assessed the business model of peer-to-peer-lendings and concluded that it has the power to influence the financial stability of banks [6]. In general, P2P-platforms have grown and established as a successful business model, thereby stating a serious challenger for traditional banks. P2P-lending excludes banks as loan providers. Mariotto and Verdier examined the success story of P2P-lending in their paper and came to an important conclusion that banks engage a serious competition in the lending business. What they point out is that the impact on loan rates for individuals and small firms remains to be seen. The assumption is that competition is changing a bank's profitability, which may lead to unfavourable loan rates for the customers [9]. The example indicates that ecosystems can lead not only to changes in market shares of participants but also to changes for customers, either good or bad, which depends on the customer's point of view. Barua et al. confirm the importance of creating an ecosystem for new revenue streams. The conducted research of the authors focuses on the business with small and medium enterprises, which shows great business for banks. Banks are recommended to start immediately on building an ecosystem by providing minimum viable products [2].

The third and last term of "open banking" can be directly associated with establishing a banking ecosystem. When integrating a third-party-provider, banks are currently and preferably using the API-technology, which stands for application programming interface. An API can be described as a standardized technical interface, which can be reused by multiple users. Moysan and Rudnicki examined in their paper the opportunities of API and came to the conclusion that using the technology enables to outstand in competitive markets [10]. In the case of ecosystems, banks can offer those API interfaces to technically integrate FinTech solutions in a cost-efficient and fast manner without providing costly and individual one-time interfaces. This saves financial investments and valuable time in the project implementation. Lees et al. state in their paper that banks could connect their core systems in favour of creating better customer experiences and hence customer satisfaction [8]. Zachariadis and Ozcan examined the chances and challenges of the API-technology for banking. Their paper stated that banks inevitably require a new way of thinking by learning how to open their customer base to new market offers. In doing so, they will be able to offer the best products and services and gain higher customer satisfaction. The authors state that API must be regarded as a valuable business opportunity and not a burden for banks [13]. Dratva also emphasizes and confirms that open banking is a current key trend that companies must not miss. However, just riding the wave is not enough, it must be done correctly and consistently go gain financial benefits [4]. Banks are generally well-advised to rethink their current strategies to compete against young innovative companies, which often prove to be more efficient and customer-oriented $[14,15]$.

\section{Methodology}

The paper focuses on the term of beyond banking, but as stated previously it is also connected to the terms of open banking and ecosystems as well. With the emphasis on beyond banking, the central research issue deals with what traditional banks can offer their customers to create new revenue streams. In doing so, it is important to understand the customer needs. Due to the omnipresence of the Internet and technology in general, customers are exposed to a variety of external influences. This leads to dynamic changes in opinions and individual needs. In addition, customers and their expectation can differ from bank to bank. It is safe to say that customers from direct or even mobile banks tend to be more digital-affine than customers from private banks. Therefore, the need to understand the individual customer base is of major relevance to approach for building a beyond banking offering.

With that said, the research of this paper starts by stating the central issue of the research. The objective is to find out what possible strategic impacts exist by applying the concept of ecosystems in traditional banking. Popular examples like Amazon have shown, that introducing a variety of different products and services can lead to a successful platform for every kind of customer demand. The thesis from the author's own professional experience in banking is that the introduction of an ecosystem in banking can be a vital approach, thereby leading to higher profits due to new sources of income. Therefore, a structured literature-review (see Table 1) is conducted to research in literature about the strategic implementations of ecosystems or beyond banking approaches. The intention is to aggregate the most relevant research findings. The literature-review includes an individual assessment by the author for each literature source to show the relevance and acknowledging the chosen publications for the given paper. Consequently, three categories derived from the review to ultimately formulate working hypotheses. The working 
hypotheses were verified by means of conducting expert interviews with representatives in banking. The chosen interviewees are longstanding experts working as inhouse consults, investment specialists, branch managers, business experts and strategists in the German banking market. Ultimately, an online survey was conducted among German retail banking clients, thereby researching about specific products and services, which are relevant in research debate and relevant according to the interviewed experts as well as according to the author's own professional banking experience. The complete research methodology is illustrated as an overview in Figure 2.

The literature-review mainly focuses on open-source publications by searching for "beyond banking", "banking ecosystem" and "open banking". Over 50 sources were analysed, whereas only 20 sources were selected due to the relevance of research findings as well as the appropriateness of the methodological approach. Conducting the review shows that the academic debate is still ongoing in terms of what to expect from beyond banking as a trend in banking. Especially the impact on traditional banking remains to be seen because many FinTechs or young companies just entered the market. Long-term track records are still missed, and many research questions require qualitative research approaches, because quantitative data is not suitable or available yet.

Overall, the synthesis of the literature-review shows that research in this field still can contribute significantly to find alignments or common grounds in terms of what to expect from the approach to offer products and services beyond the traditional offering. Hence, the motivation for this research paper is to contribute by adding precise new insights on the field of banking ecosystems. In doing so, the given research aims to provide a detailed view on what possible implementations could be done at a deeper level. The presented papers in the literature-review may indicate that there is a need for creating new revenue streams, however they often lack of showing clear strategic solution paths. From a banking point-of-view, it is not clear which products or services should be introduced to the banking customers. If papers address a specific product or service (e.g., P2P-Lending-Platforms), it may be too narrow and fail to pay justice to other vital product and service approaches. Due to those reasons, this paper intends to research the possibilities of a variety of products and services, which are in current discussions regarding a banking ecosystem. As an outcome, the research findings shall enrich the existing research base to foster new scientific works. The results should motivate bank institutions to evaluate a strategic ecosystem approach, thereby presenting first ideas with a structured prioritization on which products and services to take into consideration.

In the next research step, the paper analyses the quantitative data. The data is based on an online survey from the year 2019. The sample consists of 1224 male and 576 female participants. The majority sample age can be stated with 46 years. In terms of the net-income, the majority shows a monthly net income between 2.500 and 4.500 EUR $(\mathrm{n}=647)$. There are only a few outliers with a monthly income of over 10.000 EUR, which may not have a negative impact of the sample and the quantitative results. The survey participants were asked about a predefined set of customer needs as well as certain features offered on market (e.g., by traditional banks, FinTechs or both). The intention of using this dataset is to identify the most relevant needs for the bank's customer base and connecting it to the corresponding feature offering (e.g., need of doing tax declaration and the feature of digital tax services). Customer needs are for instance digital identity services, tax declaration services, digital safety services, online investment opportunities, digital pre-paid cards for multiple purposes, digital contract managing tools or several kinds of digital insurances. As mentioned in the beginning, the research focus lies on the beyond banking offering of banks. This implies to offer products and services beyond the classical savings account or the credit card payment method. Participants can answer whether the needs and the features are relevant or not. This research solely focuses on identifying the most relevant business opportunities to provide banks with information on starting or re-adjusting the beyond banking strategy. 


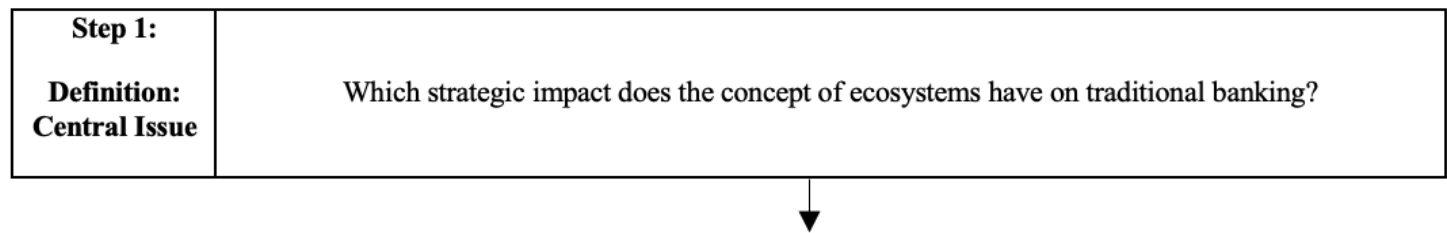

\begin{tabular}{|c|c|}
\hline Step 2: & \\
$\begin{array}{c}\text { Definition: } \\
\text { Thesis }\end{array}$ & $\begin{array}{c}\text { Ecosystems in banking lead to useful portfolio complement of banks by introducing additional } \\
\text { products and services, which are relevant to the clients. }\end{array}$ \\
\hline
\end{tabular}

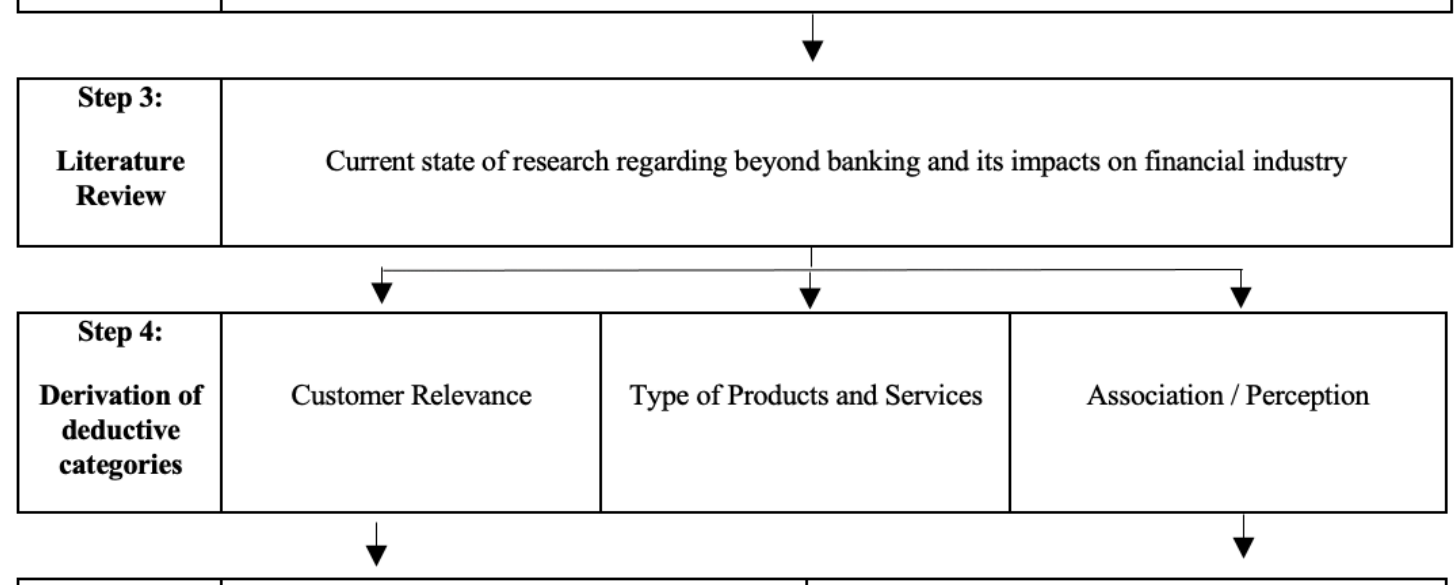

\begin{tabular}{|c|c|c|}
\hline $\begin{array}{c}\text { Step 5: } \\
\begin{array}{c}\text { Derivation of } \\
\text { extended } \\
\text { research } \\
\text { issues }\end{array}\end{array}$ & $\begin{array}{c}\text { In what way do beyond banking products and } \\
\text { services possess relevance for the banking } \\
\text { client? }\end{array}$ & $\begin{array}{c}\text { In what way do banking clients differentiate } \\
\text { between financial and non-financial products and } \\
\text { services with regards to relevance? }\end{array}$ \\
\hline
\end{tabular}

\begin{tabular}{|c|c|c|}
\hline Step 6: & \\
$\begin{array}{c}\text { Definition: } \\
\text { Working } \\
\text { Hypotheses, } \\
\text { additionally } \\
\text { verified by } \\
20 \text { expert } \\
\text { interviews }\end{array}$ & $\begin{array}{c}\text { Beyond banking products and services are } \\
\text { relevant for clients. }\end{array}$ & $\begin{array}{c}\text { Financial products and services are more relevant } \\
\text { than non-financial offers. }\end{array}$ \\
\hline
\end{tabular}

\begin{tabular}{|c|c|}
\hline $\begin{array}{c}\text { Step 7: } \\
\text { Quantitative } \\
\text { Online } \\
\text { Survey }\end{array}$ & $\begin{array}{r}\text { Researching via online questionnaire among German banking clients about their attitudes towards } \\
\text { specific financial and non-financial products as well as services. }\end{array}$ \\
\begin{tabular}{|c|c|}
\hline Step 8: \\
$\begin{array}{c}\text { Research } \\
\text { results and } \\
\text { hypothesis } \\
\text { testing }\end{array}$
\end{tabular} \\
\hline
\end{tabular}


Table 1. Structured Literature-Review with Critical Appraisal ${ }^{1}$

\begin{tabular}{|c|c|c|c|c|c|c|c|}
\hline \# & Author / Year & Title & $\begin{array}{l}\text { Type of } \\
\text { Study }\end{array}$ & $\begin{array}{l}\text { Generally Appropriate } \\
\text { research methods } \\
\text { (Coherence) }\end{array}$ & $\begin{array}{l}\text { Methods appropriate to } \\
\text { the specific research } \\
\text { question (Methodology }\end{array}$ & $\begin{array}{l}\text { Evidence appropriate to } \\
\text { the research question } \\
\text { (Relevance) }\end{array}$ & $\begin{array}{c}\text { Overall } \\
\text { Assessment }\end{array}$ \\
\hline 1 & $\begin{array}{l}\text { Balyuk, T. et al. } \\
(2020)\end{array}$ & $\begin{array}{l}\text { What is Fueling FInTech Lending? The Role of } \\
\text { Banking Market Structure }\end{array}$ & Quant. & 4 & 4 & 4 & 4 \\
\hline 2 & $\begin{array}{l}\text { Jameaba, M.-S.- } \\
\text { (2020) }\end{array}$ & $\begin{array}{l}\text { Digitization Revolution, FinTech Disruption, and } \\
\text { Financial Stability: Using the Case of Indonesian } \\
\text { Banking Ecosystem to highlight wide-ranging } \\
\text { digitization opportunities and major challenges }\end{array}$ & Quant. & 4 & 3 & 4 & 4 \\
\hline 3 & $\begin{array}{l}\text { Willem S. et al. } \\
\qquad(2020)\end{array}$ & $\begin{array}{l}\text { Opening the gates: A framework for an open banking } \\
\text { strategy }\end{array}$ & Qual. & 4 & 4 & 4 & 4 \\
\hline 4 & Dratva, R. (2020) & $\begin{array}{l}\text { Is open Banking driving the financial industry towards } \\
\text { a true electronic market? }\end{array}$ & Qual. & 3 & 4 & 3 & 3 \\
\hline 5 & $\begin{array}{l}\text { Moysan Y. \& } \\
\text { Rudnicki, M. } \\
\quad(2019)\end{array}$ & Open banking: towards platform and modular banking & Qual. & 4 & 4 & 4 & 4 \\
\hline 6 & $\begin{array}{l}\text { Al-Ajouni, A. \& } \\
\text { Al-Hakim, M. S. } \\
\text { (2019) }\end{array}$ & $\begin{array}{l}\text { Financial Technology in Banking Industry: } \\
\text { Challenges and Opportunities }\end{array}$ & Qual. & 3 & 3 & 3 & 3 \\
\hline 7 & $\begin{array}{l}\text { Kubus, R. et al. } \\
\text { (2019) }\end{array}$ & $\begin{array}{l}\text { Innovation ecosystems in banking and monetary } \\
\text { sector: competitiveness versus sustainability }\end{array}$ & Qual. & 3 & 3 & 3 & 3 \\
\hline 8 & $\begin{array}{l}\text { Diamond, S. et al. } \\
(2019)\end{array}$ & The future of banking in the platform economy & Qual. & 3 & 3 & 3 & 3 \\
\hline 9 & $\begin{array}{c}\text { Kader A. } \\
(2019)\end{array}$ & $\begin{array}{l}\text { We need banks, but not only banking: The case for } \\
\text { user-centric platform propositions beyond financing }\end{array}$ & Qual. & 3 & 4 & 3 & 3 \\
\hline 10 & $\begin{array}{l}\text { Dietz, M. et al. } \\
\qquad(2018)\end{array}$ & Banking needs an ecosystem play & Qual. & 3 & 3 & 3 & 3 \\
\hline 11 & $\begin{array}{l}\text { Jun, J. \& Yeo, E. } \\
(2018)\end{array}$ & $\begin{array}{l}\text { Peer-to-Peer Lending Platforms and the Stability of } \\
\text { the Banking System }\end{array}$ & Quant. & 4 & 4 & 4 & 4 \\
\hline 12 & $\begin{array}{l}\text { Vallee, B. \& } \\
\text { Zeng, Y. } \\
\text { (2018) }\end{array}$ & Marketplace Lending: A New Banking Paradigm? & Quant. & 4 & 4 & 4 & 4 \\
\hline 13 & $\begin{array}{l}\text { Ryan, S. G. \& } \\
\text { Zhu, C. } \\
\text { (2018) }\end{array}$ & $\begin{array}{l}\text { FinTech is not so different from traditional banking: } \\
\text { Trading off aggregation of soft information for } \\
\text { transaction processing efficiency }\end{array}$ & Quant. & 5 & 4 & 4 & 4 \\
\hline 14 & $\begin{array}{l}\text { Wewege, L. } \\
\quad(2017)\end{array}$ & $\begin{array}{l}\text { The Digital Banking Revolution: How Financial } \\
\text { Technology Companies Are Rapidly Transforming the } \\
\text { Traditional Retail Banking Industry Through } \\
\text { Disruptive Innovation }\end{array}$ & Qual. & 3 & 4 & 3 & 3 \\
\hline 15 & $\begin{array}{l}\text { Sharma, A. et al. } \\
\text { (2016) }\end{array}$ & $\begin{array}{c}\text { Learning a Disruptive Customer Engagement } \\
\text { Platform: An Empirical Analysis in the Banking } \\
\text { Industry }\end{array}$ & Qual. & 3 & 4 & 4 & 4 \\
\hline
\end{tabular}

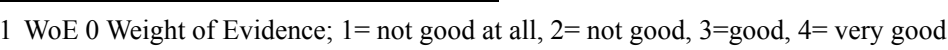


Table 1 Continued

\begin{tabular}{|c|c|c|c|c|c|c|c|}
\hline 16 & $\begin{array}{l}\text { Mariotto, C. } \\
(2016)\end{array}$ & $\begin{array}{l}\text { Competition for Lending in the Internet Era: The Case } \\
\text { of Peer-to-Peer Lending Marketplaces in the USA }\end{array}$ & Quant. & 4 & 4 & 4 & 4 \\
\hline 17 & $\begin{array}{l}\text { Zachariadis, M. \& } \\
\text { Ozcan P.(2016) }\end{array}$ & $\begin{array}{l}\text { The API Economy and Digital Transformation in } \\
\text { Financial Services: The Case of Open Banking }\end{array}$ & Qual. & 4 & 4 & 3 & 4 \\
\hline 18 & Lenz, R.(2015) & $\begin{array}{c}\text { Banking } 2025 \text { - Die Bank der Zukunft (Banking 2025: } \\
\text { The Business Model "Bank" in the Future) }\end{array}$ & Qual. & 3 & 3 & 3 & 3 \\
\hline 19 & $\begin{array}{c}\text { Mariotto, C. \& } \\
\text { Verdier, M.(2015) }\end{array}$ & $\begin{array}{l}\text { Innovation and Competition in Internet and Mobile } \\
\text { Banking: An Industrial Organization Perspective }\end{array}$ & Qual. & 3 & 3 & 3 & 3 \\
\hline 20 & $\begin{array}{c}\text { Gianiodis, P. T. et } \\
\text { al.(2014) }\end{array}$ & $\begin{array}{l}\text { Open Service Innovation in the Global Banking } \\
\text { Industry: Inside-Out Versus Outside-In Strategies }\end{array}$ & Qual. & 4 & 3 & 3 & 3 \\
\hline
\end{tabular}

Source. Own illustration 


\section{Research Findings}

\subsection{Results on an Ecosystem Offering}

The results indicate many business opportunities for traditional banks to convince customers from new products and services. Hypothesis 1, that beyond banking products and services are relevant for clients, can be regarded as true during the given research. This is enabled by using digital media and technology to provide new customer experiences, which can lead to a new level of customer satisfaction and loyalty. Presenting the findings does not imply that a bank must organically develop the products and services. It can also be provided for instance by creating an ecosystem, thereby integrating FinTechs or third-party-solutions and allowing the offering to the own customer base. In this paper, the difference between organic and inorganic offering is not making subject of discussion.

To start with, the most relevant customer need is to obtain digital vouchers. $55 \%$ of participants are interested in receiving vouchers with special price advantages. Usually, banks are not involved in the voucher business because this is mainly a domain of commercial business, especially e-commerce. There are many online platforms, which put the business of vouchers in the center of their business models. It was never a field in which banks were involved before due to its natural product portfolio. However, there are already examples on market where StartUps started a business with the focus on providing digital vouchers, thereby connecting it to the financial services industry. Customers, who are expecting incoming payments, could be offered a digital voucher instead. The idea is to provide a voucher with a higher face value than the original sum, which states the financial incentive from the customer point of view. Banks could start strategic cooperation with popular retail or commercial companies to integrate the possibility of offering digital vouchers. In doing so, a possible new revenue stream could be to receive commission payments for every successful voucher, which has been converted. This creates added value to a customer and can increase customer satisfaction and ultimately loyalty.

The second most important customer need is directly connected to the current policy of low interest rates in Europe. $51 \%$ of the survey participants stated, that they are interested in a marketplace for deposits. Such a marketplace or business model works as a financial intermediary between two parties: the customer, who wants to invest money and the product bank, which is in seek of funds. The platform brings the demand and offer together and hence receives a commission for the transaction. The concept is based on going beyond the national deposit products and making use of the different interest rates of different countries (e.g., with the European Union). This is an understandable customer need because the interest level on German deposits is close to zero. From an economic standpoint, customers are currently suffering from an effect, which is called financial repression. The interest earnings are not enough to cover the financial losses resulting from the inflation rates. Hence, customers or private investors are facing negative real returns. The need for new and especially conservative investment alternatives is thus easy to understand. Especially German customers are known for preferring deposit investments over speculative instruments such as shares, funds, or bonds. Banks could integrate such a service as an additional product to their existing product portfolio. This approach has several advantages. Firstly, banks are currently suffering from negative interest rates, which they must pay for parking surplus liquidity at the European Central Bank. This can be referred to the high amount of liquidity on the deposits of customers. By using and integrating this platform offer and allowing reducing the liquidity base, while at the same time receiving a commission fee for the successful transaction, could be highly attractive from an economic point of view. Besides, the churn of deposits can be avoided or at least controlled to a certain degree and convert it into profitable transactions.

The third customer needs deals with the idea of providing a service to manage the different digital identities of an individual. $49 \%$ of the participants are interested in this kind of service. Each person is in possession of multiple identities when using the Internet for private and business matters. One example for an identity is the e-mail account or an online account at a fashion retailer. For each digital identity, there is a login name and a password. An identity manager or service supports in keeping the different login data safe and secure, e.g., at one specific place. A bank is associated with a secure place for locking money or assets in a physical vault. The idea behind an identity managing service goes in the same direction, except it provides a digital software or platform to store data. Banks are recommended to use their good reputation regarding data protection and banking secrecy to additionally offer a digital identity service for customers. In doing so, a major customer need can be satisfied, and it strengthens the perception of the bank as a secure institution. Hypothesis 2 , that financial products and services are more relevant than non-financial offers, can be overall regarded as true. The idea of a digital identity service is not financial in its nature, but still relevant for the banking clients. However, it states one example for a non-financial service to rank among the most relevant services. Other non-financial services and products such as providing a platform for renting electronic goods or property management services.

The fourth and fifth relevant customer needs deal with digital tax services (48\%) and investment guidance in form of social trading (48\%). To start with, consultation in taxes is explicitly excluded from banks because employees are not trained in this field. Tax advisors or consultants state an 
own occupational group, which is to be distinguished from the traditional banker's job, although there might be intersections for instance when it comes to money investments. When talking about tax services, a private person is referring to the yearly tax declaration to achieve a tax refund. Expenses such as advertising costs can be declared and reduce the taxable income. An individual can either buy a tax software to manually declare the tax or consult a tax adviser. In every case, it is necessary to include the bank to submit documents or proof of payment for any declared tax positions. A house bank is in possession of all existing financial transactions of a customer. By introducing a tax service, banks could easily transfer the financial data - with the consent of the customer - to a tax service provider for finalizing the tax declaration and at the same time delivering the proof of payments.

The need for social trading deals with investing money in financial instruments. Due to the policy of low interest rates, traditional investments such as deposits are not attractive anymore. From an economic standpoint, it is detrimental to invest in deposits because of financial repression. However, many customers - and especially in Germany - are distrustful with regards to new investments. This can be referred to lack of trust, high costs, risk aversion or simply lack of knowledge. Hence, it is not surprising that the concept of social trading is gradually gaining higher recognition. The idea behind is that professional or experienced private investors - or heavy traders - share their knowledge to a broad audience of investment beginners. Professionals may use a platform do present their investment strategies or even every single transaction, so beginners can copy the strategy. In doing so, beginners can learn from professionals and find orientation where to start with an investment. The incentive for a heavy trader to share her or his knowledge is to earn commissions due to the number of followers or the number of copy-transactions. Well-known platforms on market are for example ZuluTrade or etoro.

\subsection{Recommendations for Ecosystem Implementation}

The selected presented results from the online survey provide essential starting points for traditional banks to gradually build up an ecosystem consisting of financial and non-financial products. The latter represents products or services such as providing a digital safe service for online data or travel insurances, which may not be directly associated with a bank, but rather with an insurance company. The online survey results indicate that the banking clients show a higher interest for financial products due to its proximity to existing and known offers. As presented in Figure 1 at the beginning of the paper, most German banks suffer from low RoE, thereby assuming low possibilities to massively invest in creating an ecosystem. And investing is only the first step to a possible establishment because popular examples beyond the financial industry have shown that it requires time - or even many years - to be adopted by customers. Hence, traditional banks do not only have to have the strategic foresight and the investments, but also the time to endure until banking clients perceive and accept the newly offered products and services. In the following, seven steps for traditional banks to implement an ecosystem are recommended as follows:

1. Determination and establishment of an overarching digital strategy for a specific time horizon, in which creating an ecosystem is a major part of the undertaking

2. Win of internal stakeholders to be convinced by the new strategic orientation

3. Assessment of challenges and risks by the new strategy (e.g., cannibalization risks, corporate identity)

4. Collection and prioritization of ideas for new products and services (e.g., integration of deposit platforms, digital vouchers)

5. Decision on whether the prioritized ideas are makeor buy-solutions

6. Calculation of business cases with different scenarios and net present values (NPVs) to determine the required investment budget

7. Project planning and implementation

\section{Conclusions \& Outlook}

To sum it up, traditional banks have various points to start implementing a beyond banking offering to create an ecosystem. The literature-review shows very good academic debates on the topic of beyond banking, open banking and building an ecosystem. However, it does not show the diversity of possible new products and services. Many examined research papers focus on P2P-lending as innovative new service by FinTechs, which are currently challenging market incumbents. But the analysis of the quantitative dataset shows a much broader range of possible implementation opportunities for banks. The paper introduced the five most relevant customer needs and translated it into clear recommendations for possible new revenue streams. Many of the customer needs can be directly referred to financial matters, thereby making it a suitable starting point for banks. The examples of social trading, crowd investing, digital deposit platforms and digital safes or vaults can be related to investment products and the reputation for a bank as a repository for valuable assets. Moreover, the needs for pre-paid-cards, vouchers and different kinds of digital services show an interesting approach to make daily life of customers easier. Although not directly associated with banks, it could be a vital approach to create a new offering in seeks of new revenue streams. In doing so, banks can create their own USPs and achieve an even higher customer retention to defend against other competitors. This contributes to the existing 
academic debate and shall expand the scope for further research in the fields of beyond banking, ecosystems, and open banking.

The given research work is subject to some limitations. First, the target group of the survey is German banking customers. The results thus are mainly eligible to consider for banks operating on the German market. It is well known in the financial industry that there are cultural differences in terms of investment behaviour and preferences between the nations. For instance, Germans tend to be more conservative (e.g., savings accounts governmental bonds), whereas Americans are known for their preference toward more offensive investment opportunities (e.g., shares, funds). Therefore, the survey results in this paper may be taken into consideration with caution, when referred to the American banking market. Another limitation is that the ecosystem-universe offers way more products and services, which were not subject in this survey. The intention of this paper is to focus on the mainly driven from the author's point-of-view - most relevant features. The last limitation to mention is that the research is using descriptive statistics as a first approach to analyse the research question. More sophisticated methods such as logistic regressions or other statistical analyses may deliver more valid academic proof.

For further research, it is recommended to gain further quantitative data by surveying more customers from different banks (e.g., universal bank, online bank, neobank). Each bank has its own unique customer structure. Especially the German banking market is divided in three different types of banks: (i) commercial banks, (ii) public-sector banks and (iii) cooperative banks. This is also referred to as the three-pillar-structure in German banking. However, this concept does not include the modern developments and rise of neobanks or FinTechs yet. The new types of banks create new customer experiences and thus new customer types. It may be eligible to integrate this fact in further research regarding the banking systems or markets. Also, manifold further criteria can play a significant role when it comes to the establishment of an ecosystem. The demographic change as well as the upcoming change of generations is two exemplary strong factors, which may have an impact on the success of beyond banking approaches. In-depth interviews could improve research findings by understanding the customer needs better and provide banks with more specific guidance to achieve a customer-centric approach.

Despite this great potential and the customers' desire to implement components of the Beyond Banking approach, which was confirmed by the qualitative survey, there are also some challenges to be considered from the bank's point of view.

On the one hand, there are still few or hardly any practical examples that banks can refer to. On the other hand, the expansion of a beyond banking approach is cost-intensive and requires a high level of technical experience. As a result, this could be a financial risk in terms of low bank earnings.

It should also be emphasized that this survey covers only a small part of consumer needs, so consumers may demand non-financial products or services from other providers despite an eco-banking system.

\section{REFERENCES}

[1] Balyuk, T., Berger, A. N. and Hackney, J (June 2020). What is Fueling FinTech Lending? The Role of Banking Market Structure (June 23, 2020). Available: https://ssrn.com/abstr act $=3633907$

[2] Barua, C. et al. (June 2019). Beyond Banking: How banks can use ecosystems to win in the SME market [Online]. Available:https://www.mckinsey.com/ /media/mckinsey/i ndustries/financial\%20services/our\%20insights/how\%20b anks $\% 20$ can $\% 20$ use $\% 20$ ecosystems $\% 20$ to $\% 20$ win $\% 20$ in $\% 20$ the $\% 20$ sme $\% 20$ market/how-banks-can-use-ecosystem s-to-win-in-the-sme-market-vf.ashx

[3] Brackert, T. et al. (October 2019). Global Retail Banking 2019: The Race for Relevance and Scale [Online]. Available: https://www.bcg.com/de-de/publications/2019/ global-retail-banking-race-for-relevance-scale

[4] Dratva, R. (2020), "Is Open Banking Driving the Financial Industry towards a True Electronic Market?", in: The International Journal on Networked Business 30, no. 1 (2020): 65 .

[5] Gianiodis, P. T., Ettlie, J. E. and Urbina, J. J. (2014), “Open Service Innovation in the Global Banking Industry: Inside-Out Versus Outside-In Strategies", in: Academy of Management Perspectives, [s. 1.], v. 28, n. 1, p. 76, 2014.

[6] Jun, J. and Yeo, E. (July 2018), Peer-to-Peer Lending Platforms and the Stability of the Banking System (July 29, 2018). 31st Australasian Finance and Banking Conference 2018, Available at: https://ssrn.com/abstract=3221966

[7] Kader, A. (2019), "We need banks, but not only in banking: The case for user-centric platform propositions beyond financing", in: Journal of Digital Banking, 4(2), 175-183.

[8] Lees, C. et al. (April 2019). APIs: The Digital Glue, How Banks can Thrive in an API Economy [Online]. Available: https://www.accenture.com/_acnmedia/PDF-100/Accentur e-How-Banks-Can-Thrive-API-Economy.pdf

[9] Mariotto, C. and Verdier, M. (2015), "Innovation and Competition in Internet and Mobile Banking: An Industrial Organization Perspective", in: Bank of Finland Research Discussion Paper No. 23/2015.

[10] Moysan, Y., and Rudnicki, M. (2019), “Open banking: Towards platform and modular banking. Journal of Digital Banking”, 4(2), 131-143.

[11] Ryan, S. G. and Zhu, C. (July 2018). Fintech Isn't So Different From Traditional Banking: Trading Off Aggregation of Soft Information for Transaction Processing Efficiency (July 12, 2018). Available: https://ssrn.com/abst ract $=3212902$ 
[12] Standaert, B. W., Muylle, B. S. and Cumps, B. B. (2020), "Opening the gates: A framework for an open banking strategy", in: Journal of Digital Banking, 4(4), 364-376.

[13] Zachariadis, M. and Ozcan, P. (2017), "The API Economy and Digital Transformation in Financial Services: The Case of Open Banking", SWIFT Institute Working Paper No. 2016-001.
[14] Anto, R., Rini, I. and Purwandarim E. , "Determinants of Bank Efficiency in ASEAN5: Size as a Control Variable", Universal Journal of Accounting and Finance, Vol. 9, No. 4, pp. 542 - 547, 2021. DOI: 10.13189/ujaf.2021.090402.

[15] Anamali, A., Zisi, A. and Shosha, B., "Banking Service in Albania: Satisfied... from what?", Universal Journal of Accounting and Finance, Vol. 9, No. 4, pp. 735 - 744, 2021. DOI: 10.13189/ujaf.2021.090419. 